L A B O R D I I D E D 



\section{LABOR DIVIDED}

Austerity and Working-Class Politics in Contemporary Italy

MIRIAM GOLDEN

Cornell University Press

ITHACA AND LONDON 


\section{Copyright (C) 1988 by Cornell University}

All rights reserved. Except for brief quotations in a review, this book, or parts thereof, must not be reproduced in any form without permission in writing from the publisher. For information, address Cornell University Press, I 24 Roberts Place, Ithaca, New York 14850.

First published 1988 by Cornell University Press.

International Standard Book Number 0-80 I4-2200-0

Library of Congress Catalog Card Number 88-47726

Librarians: Library of Congress cataloging information appears on the last page of the book.

The paper in this book is acid-free and meets the guidelines for permanence and durability of the Committee on Production Guidelines for Book Longevity of the Council on Library Resources. 